\title{
The Effects of Psychological Distress, Work, and Family Stressors on Child Behavior Problems
}

Daphne C. Watkins*

Chavella T. Pittman"*

Marissa J. Walsh"“”

\section{INTRODUCTION}

Each year, thousands of children experience behavior problems resulting from their environmental influences, school and peer interactions, home and family settings, or any combination of these situational occurrences. Regardless of developmental stage, problems experienced by children may influence their ability to transition to and through appropriate life stages and develop into healthy and socially functional adults. Decades of research on child behavior problems have included approaches that established what we know as the current body of knowledge on this subject area. Early studies on child behavior problems included cross-sectional studies that compared rates of childhood disturbance with demographic information about families (Christensen, Phillips, Glasgow, \& Johnson, 1983; Dadds, Sanders, Morrison, \& Rebgetz, 1992; Greenbaum, Dedrick, Friedman, Kutash, Brown, Lardieri, \& Paugh, 1996). Observational studies that demonstrated functional relationships between child and parent behaviors were also a part of the early research in this area (Altmann \& Gotlib, 1988; Gardner, 2000). Theoretical writings that integrated data in order to broaden the view about the nature and course of child and family behaviors emerged from these early studies and characterized the multiple components that affect the development and maintenance of childhood behaviors (Dadds, 1987; Greenberg, Speltz, \& Deklyen, 1993; Piquero, Farrington, Welsh, Tremblay, \& Jennings, 2009). These approaches also helped researchers and practitioners acquire information about the societal, political, and parental factors that influence child behavioral outcomes-particularly with regard to how parents' mental health affects child behavior outcomes.

Recent studies have focused on describing the influence of family factors on child behavioral outcomes, and one factor that has received considerable attention is the mental health of the parents. For example, studies have underscored associations between parental depression/anxiety and child behavior problems (Meadows, McLanahan, \& Brooks-Gunn, 2007) as well as the link between maternal psychological distress, family income, marital conflict, parenting, and children's outcomes in early and middle childhood (Nievar \& Luster, 2006). Among a diverse sample of primarily Black, White, and Hispanic parents, Meadows, McLanahan, and Brooks-Gunn (2007) reported a multiplicative association between parental mental illness and child behavior problems and identified differences among married versus cohabitating parents and resident versus nonresident fathers. The authors

*University of Michigan, School of Social Work, 1080 South University Avenue, Ann Arbor, Michigan 481091106, U.S.A.

** Dominican.University, 7900 West Division Street, River Forest, IL 60305.U.S.A.

*** University of Michigan, School of Social Work, 1080 South University Avenue, Ann Arbor, Michigan 48109 1106, U.S.A. 
called for future studies that explore mechanisms by which parents' mental health predicts child behavior problems and the racial/ethnic differences that exist within this context. Applying McLoyd's (1990) family stress model, Nievar and Luster (2006) found racial/ethnic differences in martial conflict among African American and non-Latino White families; however, they did not examine the influence of psychological distress in their study. The aforementioned studies are evidence that, to date, there has been notable work on child behavior problems and parental mental health measures as well as the influence of marital conflict on child behavioral problems. Yet, what remains unexplored is the influence of psychological distress and work and family stressors (e.g., work/family balance, work hassles, and marital conflict) on child behavior problems. The present study seeks to fill a gap in this literature by examining the influence of sociodemographic variables, psychological distress, and work and family stressors on child behavior problems.

\section{The Influence of Work and Family Stressors on Children}

The functionality of the family as a collective unit has implications for child behavior problems. One example is the link between socioeconomic status (SES), parental mental health, and its influence on child behavior. For example, poverty is a major mental health determinant for adults (McLeod \& Nonnemaker, 1999) and children (Dearing; McCartney, \& Taylor, 2006) and previous studies have reported lower depression prevalence rates among individuals with high SES (Blazer, Kessler, McGonagle, \& Swartz, 2004). Therefore, if parents who experience low SES and psychological distress find it difficult to seek care and resources for themselves, then they may likely experience difficulty caring for their children. The psychologically distressed parent who is lacking the care and resources they need to function as an individual may neglect their child in the endeavor to pursue such resources. Subsequent behavior problems and other psychological and emotional conditions are sometimes the result of child neglect on the part of the parents (De Bellis \& Thomas, 2003; Springer, Sheridan, Kuo, \& Carnes, 2007). Thus, psychologically distressed parents who are in need of healthcare resources for themselves can exacerbate their child's behavior problems (Thomas \& Evelyn, 2004).

Two decades of research report conflicting findings regarding parental work and family habits on the family and child outcomes. For example, a 1999 review by Harvey using the National Longitudinal Study of Youth (NLSY) data found that neither early maternal nor paternal employment status consistently affected child outcomes, despite the conflicting results of earlier studies (see review by Perry-Jenkins, Repetti, \& Crouter, 2000). These effects were not moderated by job satisfaction or race (Perry-Jenkins, Repetti, \& Crouter, 2000). Parents with more pressures at work tend to report greater role overload and an overwhelming feeling from multiple commitments (Crouter, Bumpus, Maguire, \& McHale, 1999). Overall, the conditions under which parents work have an effect on child and family relations. As such, people who report more conflict and overload resulting from the combination of work and family roles also report more emotional distress (Paden \& Buehler, 1995), and these experiences contribute to problematic parent-child interactions and negative child outcomes (Bowen, 1998).

Abidin's (1995) parenting stress index suggests that parenting behaviors mediate the relationship between parenting stress and children's emotional and behavioral difficulties. In other words, parent's stress influences their behavior, which in turn affects their children's adjustment and outcomes. Parenting hassles predict fewer observed material positive behaviors and less positive relationships beyond the effects of life stressors (Crnic, Gaze, \& Hoffman, 2005). Relatively high-risk families experience consistent associations between 
parenting hassles, non-parenting hassles, and parent psychological adjustment (Creasey \& Reese, 1996). Similarly, context-specific hassles such as marital status and spousal problems, occupational status and stressors, the ability to balance work and family responsibilities, and feelings about being a parent all influence the psychological adjustment of parents and the presence of child behavior problems.

Constant exposure to the marital and relationship transitions of parents can lead to poor behavior outcomes among children (Cavanaugh \& Huston, 2006). Oftentimes when parents end their relationship, not only does it affect the children emotionally, but there are also financial repercussions that affect the children and the household. For instance, Nievar and Luster (2006) found marital conflict to be a significant predictor of child behavior problems among African American families. Maternal depression mediated the association between marital conflict and child behavior problems for only the African Americans in their sample. Such findings could imply that children of low-income mothers may be more likely to experience behavior problems. Generally, low-income families also experience economic stress and engage in more physical disciplinary practices which both contribute to increased child behavior problems (Anthony, Anthony, Glanville, Naiman, Waanders, \& Shaffer, 2005; Nievar \& Luster, 2006; Olson Ceballo, \& Park, 2002).

\section{The Influence of Parental Psychological Distress on Children}

Childhood development is disturbed when parents are psychologically distressed and engage in distressing internalized and externalized behaviors (Jaffee, Moffitt, Caspi, \& Taylor, 2003). Studies that examine the association between the parents' mental health and child outcomes oftentimes exclude cohabitating couples and parents residing in separate households, also known as "nontraditional families." Given that children raised in nontraditional families are more likely to experience the risks associated with the mental disorders of their parents this produces a limitation in the research (Carlson \& Corcoran, 2001). Nontraditional families tend to face more challenges than traditional families, such as low SES, instability, and fewer parenting resources. Single mother households are also considered "nontraditional families," and early studies discerned that clinically depressed, non-partnered mothers were more likely to have children with depressive disorders, anxiety, and subsequent conduct disorders (Mowbray, Bybee, Oyserman, Allen-Meares, MacFarlane, \& Hart-Johnson, 2004; Mufson, Nomura, \& Warner, 2002). An increase in the number of nontraditional families over the years raises the question regarding whether, and to what extent, do the mental disorders of these parents influence child behavioral outcomes.

Studies have reported on the advantages and disadvantages of maternal versus paternal mental disorders and their influence on family functioning and child behavior outcomes (Marmorstein, Malone, \& Iacono, 2004; Mezulis, Hyde, \& Clark, 2004). Maternal depression leads to outcomes that directly affect the mother, such as emotional disengagement from children and expressing less affection (Bigatti, Cronan, \& Anaya, 2001); as well as outcomes that affect the household, such as economic adversity, life stress, and deficient sources of social support (Naerde, Tambs, \& Mathiese, 2002; Petterson \& Albers, 2001; Reading \& Reynolds, 2001). Similarly, the child may also experience poor outcomes, such as aggression and unsuccessful social interactions with their peers (Leiferman, 2002). Research in this area links maternal mental disorders with distress for the entire family, whereas the presence of a healthy father can serve as a protective factor for the children and reduce disorders and problems (Kahn, Brandt, \& Whitaker, 2004). Studies on parental mental health and its influence on the behaviors of children suggests that maternal disorders are more detrimental than paternal disorders and having one healthy parent can 
buffer the negative effects that the child may experience from the unhealthy parent (Beardslee, Versage, \& Gladstone, 1998; Phares, Duhig, \& Watkins, 2002).

Previous studies present evidence suggesting that the characteristics of parental mental health influence child behavior outcomes, and have replicated across samples in the literature. Yet, the influence of parent mental health on child behavior problems in addition to work-and family-level characteristics (i.e., parental psychological distress, work hassles, spousal problems) is an area of research that remains unexplored. Therefore, the present study seeks to add to previous research on child behavior problems by examining the influence of sociodemographic variables, psychological distress, and work and family stressors on the behaviors of children using respondents from the 1995 Detroit Area Study. We proceed in an attempt to answer the question: how does psychological distress influence child behavior problems once stressors such as socio-demographic variables (i.e., age of parents, household size, and education of parents), parents' work, and family demands are considered? An exhaustive look at the relationship between family type (traditional vs. nontraditional), parents' mental health, and child behavior problems is beyond the scope of this study. Yet, we include household size (i.e., number of persons in the household) and marital status as important indicators that may help to discern family characteristics. The present study does not include a breakdown of paternal versus maternal factors. Rather, we focus our analysis on the inclusion of a combined marital status/ spousal problems measure as a family stressor that might influence the parents' mental health with the hope of acquiring insight about the characteristics of parents who experience child behavior problems versus those who do not.

\section{METHODS}

\section{Study Data}

This study used the 1995 Detroit Area Study (DAS) data, a multistage probability survey conducted in 1995 to assess the ways in which social influences can affect health and influence personal life. Respondents eighteen years of age or older who lived in the Michigan counties of Macomb, Oakland, and Wayne were randomly selected from each eligible household. University of Michigan interviewers conducted face-to-face interviews with respondents between April and October of 1995. The response rate was $70 \%$ (see Williams, Yu, Jackson, \& Anderson, 1997 for details on the 1995 DAS) resulting in 1,139 respondents. The analyses for this study focused on the subset of respondents who reported that they had at least one child $(N=851)$. The sampling frame is representative of the Detroit Metro area; therefore, our results are generalizable only to that area. However, findings may also be representative of areas with similar characteristics.

\section{Measures}

\section{Socio-Demographic Variables}

Age; household size; and education were included as the sociodemographic measures of study respondents. We represented age by creating a categorical variable with four age groups (i:e., 18 - 34, 35 - 54, $55-64,65+$ ). Also represented as a categorical variable, household.size had five categories representing one, two, three, four, and five or more persons in the household. Education was a four category variable of those with less than a high school diploma, a high school diploma, some college, and a college degree or more. Preliminary analyses included race, gender, and income. Yet, these sociodemographic 
variables were not statistically significant and thus were not included in the analyses.

\section{Psychological Distress}

Psychological distress (Kessler, Andrews, Colpe, Hiripi, Mroczek, Normand, Walters, \& Zaslavsky, 2002) was measured using the Kessler 6 scale (K6), which asks "in the last thirty days, how often did you feel: so sad nothing could cheer you up, nervous, restless/fidgety, hopeless, everything was an effort, and worthless." Higher scores on this variable represent higher levels of psychological distress. Respondents indicated how often they experienced these symptoms using the following.5-point Likert scale: $4=$ all of the time, $3=$ most of the time, $2=$ some of the time, $1=$ a little of the time, and $0=$ none of the time. We scored the K6 using the un-weighted average of the total responses. Scores led to classifying respondents at low, moderate, high, or very high risk. A K6 score of 12 to 24 is very high risk: The K6 has demonstrated favorable internal consistency and reliability (Cronbach's $\alpha=0.89$ ) and has consistent psychometric properties across major sociodemographic sub samples.

\section{Work and Family Stressors}

We measured work and family stressors using four measures: "bothered as a parent," "work hassles," "trouble balancing work and family," and "marital status/spousal problems." Bothered as a parent asked how often did the respondents feel bothered or upset as a parent. The five response categories ranged from "very often" to "never." Work hassles were assessed by asking respondents to respond "yes" or "no" to whether they experienced "hassles at work" in the past month. To assess trouble balancing work and family demands, respondents provided a "yes" or "no" response to the question: "in the last month have you experienced trouble balancing work and family demands?" We assessed spousal problems by asking if, in the past month, respondents had experienced any problems with their, spouse/partner. Response categories were "yes," "no," or "inapplicable" (i.e., for those who were unmarried or divorced). Marital status (i.e., divorced or married) was also represented by the spousal problems question.

\section{Child Behavior Problems}

The dependent variable of interest for this study was child behavior problems. This variable was comprised of one item that asked the respondents if they had experienced any problems with their child/children in the past month. The response categories for the dependent variable were "yes," or "no." This dichotomous dependent variable poses a limitation, as the binomial nature of this variable may not capture the complexity of behavioral difficulties among children. Although this binary outcome may appear limited, previous studies have shown that important questions can be answered with binary outcome variables (Kirby, 2002; Kuhns \& Widom, 1996; Slade \& Wissow, 2004; Todorova, Falcón, Lincoln, \& Price, 2010). In the present study, the dependent variable will help to determine how well the model explains membership in the child behavior problems group and the extent to which each predictor contributes to the probability of a case being in the child behavior problems group as opposed to the no child behavior problems group.

\section{Data Analysis}

A primary aim of this study was to understand the contexts by which psychological distress, sociodemographic variables, and work and family stressors influence child behavior problems. We ran descriptive analyses for the sociodemographic variables to identify 
sample characteristics. Initial statistical analysis compared child behaviors problems across the categorical sociodemographic variables, psychological distress, and family stressors using crosstabs with chi-square tests. Next, we ran a series of logistic regression models to examine the associations between sociodemographic variables, parental psychological distress, family and work stressors and child behavior problems. The first model included sociodemographic variables, the second model added a psychological distress variable, and the third model included work and family stressors. We used the Statistical Package for Social Sciences (SPSS version17; Chicago, IL) to conduct the analyses for this study.

\section{RESULTS}

Table 1 presents a composite list of the sample sociodemographic characteristics. Respondents were primarily females (64.7\%) between the ages of 35 and 64 (44.1\%), with two individuals living in the household $(26.9 \%)$, a high school diploma $(33.4 \%)$, and incomes between $\$ 20,000$ and $\$ 39,999(26 \%)$. Almost three fourths of the respondents were married or living with a partner $(72 \%)$ and over half were White $(55.4 \%)$. Three-fourths of respondents reported experiencing no work hassles (75\%) and no work/family balancing problems $(72.7 \%)$. More than half of the married respondents reported experiencing no spousal problems $(57.2 \%)$ and thirty-seven percent reported feeling bothered as a parent "not too often." In addition, the average score of the psychological distress scale was 1.90 $(\mathrm{SD}=.794)$ and the average number of children was $2.72(\mathrm{SD}=1.73)$.

Table 2 presents the prevalence of child behavior problems across the categorical predictor variables (i.e., sociodemographic variables, work, and family stressors). Based on the chisquare tests, each of the categorical predictors had a significant relationship with child behavior problems. Parents aged $18-34(36.5 \%)$ and $35-54(40 \%)$ experienced the most child behavior problems of all the age groups. Respondents with a high school diploma reported fewer $(26.7 \%)$ child behavior problems than those with other educational backgrounds. Child behavior problems were most prevalent (48.2\%) in five or more person households. Parents who reported not being able to balance work and family life had more child behavior problems than those who reported that they could balance their work and family life (55.5\% and $23.3 \%$, respectively). Married respondents with no spousal problems also reported no child behavior problems $(73.3 \%)$. Those who were divorced or married with spousal problems had almost a 50-50 chance of experiencing child behavior problems (43.0\% and $44.5 \%$,respectively). Respondents with no hassles at work also reported no child behavior problems $(72.5 \%)$ and across the categorical predictors, the majority $(44.5 \%$ $82.7 \%$ ) of parents reported no child behavior problems.

\section{Socio-Demographic Variables and Child Behavior Problems}

The first logistic regression model examined the influence of the socio-demographic variables on child behavior problems' (Table 3$)$. Parents aged 18 to $34(\mathrm{OR}=.472 ; \mathrm{p}<.01)$ and 35 to $54(\mathrm{OR}=.364 ; \mathrm{p}<.001)$ were more than twice as likely to experience child behavior problems as parents 65 years and older. Respondents in single-person households reported the lowest odds $(\mathrm{OR}=3.18 ; \mathrm{p}<.01)$ of having child behavior problems compared to the two $(O R=1.92 ; \mathrm{p}<.05)$, three $(O R=1.60 ; \mathrm{p}<.05)$ and four $(O R=1.68 ; \mathrm{p}<.05)$ person households that also had lower odds of having child behavior problems. Those who had a high school education were least likely $(\mathrm{OR}=1.64 ; \mathrm{p}<.05)$ to have child behavior problems

\footnotetext{
'Results reported in Tables 3,4, and 5 correspond with the text. However, using "no child behavior problem:" in the tables and "child behavior problems" in the text helped us avoid double-negative language that often occurs during the interpretation and reporting of odds ratios.
} 
Table 1

Characteristics of the Sample.

\begin{tabular}{|c|c|c|c|}
\hline Variable & $\mathrm{N}(\%)$ & Variable & $N(\%)$ \\
\hline Age of respondents & & Marital Status & \\
\hline $18-34$ & $198(23.3 \%)$ & Divorced/Separated & $174(28.0 \%)$ \\
\hline $35-54$ & $375(44: 1 \%)$ & Married/Living with partner & $448(72.0 \%)$ \\
\hline $55-64$ & $112(13.2 \%)$ & & \\
\hline \multirow[t]{2}{*}{$65+$} & $166(19.5 \%)$ & Race & \\
\hline & & African American & $456(44.6 \%)$ \\
\hline Household size & & White & $367(55.4 \%)$ \\
\hline 1 & $166(19.5 \%)$ & " & \\
\hline 2 & $229(26.9 \%)$ & Work hassles & \\
\hline 3 & $181(21.3 \%)$ & Yes & $209(25 \%)$ \\
\hline 4 & $159(18.7 \%)$ & No & $626(75 \%)$ \\
\hline & $116(13.6 \%)$ & & \\
\hline & & Work family balance problems & \\
\hline Education & & Yes & $229(27.3 \%)$ \\
\hline Less than high school & $133(15.6 \%)$ & No & $609(72.7 \%)$ \\
\hline High school diploma & $284(33.4 \%)$ & & \\
\hline Some college & $260(30.6 \%)$ & Marital status/Spousal problems & $\cdot$ \\
\hline \multirow[t]{2}{*}{ College degree } & $174(20.4 \%)$ & Divorced/Inap. & $174(28.1 \%)$ \\
\hline & & Married/No & $354(57: 2 \%)$ \\
\hline Income & & Married/Yes & $91(14.7 \%)$ \\
\hline$<\$ 10,000$ & $149(17.5 \%)$ & & \\
\hline$\$ 10,000-\$ 19,999$ & $127(14.9 \%)$ & Bothered as a parent & \\
\hline$\$ 20,000-\$ 39,999$ & $221(26.0 \%)$ & Very often & $81(9.6 \%)$ \\
\hline$\$ 40,000-\$ 59,999$ & $134(15.7 \%)$ & Fairly often & $130(15.4 \%)$ \\
\hline \multirow[t]{2}{*}{$\$ 60,000>$} & $220(25.9 \%)$ & Not too often & $318(37.6 \%)$ \\
\hline & & Hardly Ever & $206(24.4 \%)$ \\
\hline Gender & & Never & $110(13 \%)$ \\
\hline Female & $551(64.7 \%)$ & & \\
\hline \multirow[t]{2}{*}{ Male } & $300(35.3 \%)$ & Psychological distress mean (SD) & $1.90(.794)$ \\
\hline & & \# of Children mean (SD) & $2.72(1.73)$ \\
\hline
\end{tabular}

than those from other education categories.

\section{Socio-Demographic Variables, Psychological-Distress, and Child Behavior Problems}

The second logistic regression model was built on the first logistical regression model and examined the influence of sociodemographic variables and psychological distress on child behavior problems (Table 4). Similar to the first model, parents aged 18 to $34(\mathrm{OR}=.481 ; \mathrm{p}<$ $.05)$ and 35 to $54(\mathrm{OR}=.400 ; \mathrm{p}<.001)$ were twice as likely to have child behavior problems as parents 65 years and older in the second model. Respondents in single-person households were also less likely $(\mathrm{OR}=3.27 ; \mathrm{p}<.001)$ to experience child behavior problems. The two $(\mathrm{OR}=1.88 ; \mathrm{p}<.05)$ and four $(\mathrm{OR}=1.61, \mathrm{p}<.05)$ person households had lower odds of experiencing child behavior problems than five or more person households. Respondents with a high school diploma $(\mathrm{OR}=1.97 ; \mathrm{p}<.01)$ and some college $(\mathrm{OR}=1.66 ; \mathrm{p}<.05)$ were about half as likely to have child behavior problems as the college educated respondents. 
Table 2

Prevalence of Child Behavior Problems Across Categorical Predictor Variables

\begin{tabular}{|c|c|c|c|}
\hline \multicolumn{4}{|c|}{ Child Behavior Problems } \\
\hline & $\chi 2(\mathrm{df})$ & Yes & No \\
\hline Age $(n=827)$ & $32.39(3)^{* * *}$ & & \\
\hline $18-34$ & & $36.5 \%$ & $63.5 \%$ \\
\hline $35-54$ & & $40.0 \%$ & $60.0 \%$ \\
\hline $55-64$ & & $23.7 \%$ & $76.3 \%$ \\
\hline $65+$ & & $17.3 \%$ & $82.7 \%$ \\
\hline Education $(n=827)$ & $14.33(3)^{* *}$ & & \\
\hline$<$ High School & & $41.7 \%$ & $58.3 \%$ \\
\hline High School & & $26.7 \%$ & $73.3 \%$ \\
\hline Some College & & $28.6 \%$ & $71.4 \%$ \\
\hline College Degree & & $36.8 \%$ & $63.2 \%$ \\
\hline Household Size $(n=827)$ & $32.57(4)^{* * *}$ & & \\
\hline 1 person & & $17.4 \%$ & $82.6 \%$ \\
\hline 2 person & & $24.8 \%$ & $75.2 \%$ \\
\hline 3 person & & $32.8 \%$ & $67.2 \%$ \\
\hline 4 person & & $36.5 \%$ & $63.5 \%$ \\
\hline 5 or more persons & & $48.2 \%$ & $51.8 \%$ \\
\hline Work/family balance problems $(n=806)$ & $77.17(1)^{* * *}$ & & \\
\hline Yes & & $55.5 \%$ & $44.5 \%$ \\
\hline No & & $23.3 \%$ & $76.7 \%$ \\
\hline Hassles at work $(n=809)$ & $26.73(1)^{* * *}$ & & \\
\hline Yes & & $47.2 \%$ & $52.8 \%$ \\
\hline No & & $27.5 \%$ & $72.5 \%$ \\
\hline Marital status, Spousal problems $(n=686)$ & $20.11(2)^{* * *}$ & & \\
\hline Divorced & & $43.0 \%$ & $57.0 \%$ \\
\hline Married, No & & $26.7 \%$ & $73.3 \%$ \\
\hline Married, Yes & & $44.5 \%$ & $55.5 \%$ \\
\hline
\end{tabular}

Child behavior problems were twice as likely (OR $=.484 ; \mathrm{p}<.001)$ to occur among respondents who reported experiencing psychological distress.

\section{Socio-Demographic Variables, Psychological Distress, Work and Family Stressors, and Child Behavior Problems}

The third logistic regression model examines the influence of sociodemographic variables, psychological distress, and family and work stressors on child behavior problems (Table 5). As in the previous models, respondents aged 18 to $34(\mathrm{OR}=.359)$ and 35 to $54(\mathrm{OR}=.424)$ were most likely to experience child behavior problems compared to respondents aged 65 and older. Parents with a college degree were about half as likely as parents with a high school diploma $(\mathrm{OR}=1.95 ; \mathrm{p}<.05)$ and some college $(\mathrm{OR}=2.06 ; \mathrm{p}<.05)$ to experience no child behavior problems. Psychologically distressed respondents $(O R=.744 ; p<.05)$ were 1.3 times more likely to experience child behavior problems than those who were not distressed. Those who were bothered as a parent $(O R=2.55 ; p<.001)$ and reported work family balance problems $(\mathrm{OR}=.466 ; \mathrm{p}<.001)$ were twice as likely to have child behavior problems. Parents who were divorced were nearly 2.5 times as likely to have child problems than parents who were married and did not have spousal problems $(O R=2.45 ; p<.05)$. 
Table 3

Logistic Regression Analysis of Sociodemographic Variables Predicting no Child Behavior Problems (Model 1)

\begin{tabular}{|c|c|c|c|c|c|}
\hline \multirow[b]{2}{*}{ Variable } & \multicolumn{5}{|c|}{ No Child Behavior Problems $(n=844)$} \\
\hline & B & SE & $\begin{array}{l}\text { Odds } \\
\text { ratio }\end{array}$ & $\begin{array}{l}\text { Wald } \\
\text { Statistic }\end{array}$ & $\begin{array}{l}95 \% \\
\text { C. I. }\end{array}$ \\
\hline $\begin{array}{l}\text { Age } \\
\qquad \begin{array}{r}18-34 \\
35-54 \\
55-64 \\
65+\#\end{array}\end{array}$ & $\begin{array}{l}-.751 \\
-1.01 \\
-.406\end{array}$ & $\begin{array}{l}.280 \\
.253 \\
.305\end{array}$ & $\begin{array}{l}.472 \\
.364 \\
.666\end{array}$ & $\begin{array}{l}17.42^{* * *} \\
7.18^{* *} \\
15.91^{* * *} \\
1.77\end{array}$ & $\begin{array}{l}.27-.82 \\
.22-.60 \\
.37-1.2\end{array}$ \\
\hline $\begin{array}{c}\text { Household Size } \\
\quad 1 \\
2 \\
3 \\
4 \\
5+\#\end{array}$ & $\begin{array}{l}1.16 \\
.654 \\
.469 \\
.516\end{array}$ & $\begin{array}{l}.347 \\
.255 \\
.238 \\
.232\end{array}$ & $\begin{array}{l}3.18 \\
1.92 \\
1.60 \\
1.68\end{array}$ & $\begin{array}{l}13.11^{* *} \\
11.11^{* * *} \\
6.58^{* *} \\
3.89^{*} \\
4.96^{*}\end{array}$ & $\begin{array}{l}1.6-6.3 \\
1.2-3.2 \\
1.0-2.5 \\
1.1-2.6\end{array}$ \\
\hline $\begin{array}{l}\text { Education } \\
\text { Less than HS } \\
\text { HS } \\
\text { Some college } \\
\text { College degree \# }\end{array}$ & $\begin{array}{l}-.243 \\
.494 \\
.433\end{array}$ & $\begin{array}{l}.244 \\
.233 \\
.241\end{array}$ & $\begin{array}{l}.784 \\
1.64 \\
1.54\end{array}$ & $\begin{array}{l}15.97 * * * \\
.995 \\
4.48^{* *} \\
3.24\end{array}$ & $\begin{array}{r}.49-1.3 \\
1.02 .6 \\
.96-2.5\end{array}$ \\
\hline Constant & .717 & .336 & 2.05 & $4: 55^{*}$ & \\
\hline
\end{tabular}

${ }^{*} p<.05 .{ }^{* *} p<.01 .{ }^{* * *} p<.001 .$, Nagelkerke $R^{2}=.105$, \# comparison category

\section{DISCUSSION}

The purpose of this study was to examine the influence of sociodemographic variables, psychological distress, and work and family stressors on child behavior problems using the 1995 Detroit Area Study. We sought to uncover the influence of psychological distress on child behavior problems once other work and family stressors were considered. Overall, our models revealed that parents' age is an important predictor for child behavior problems. Not surprising, younger parents were more likely to experience child behavior problems than the older parents in our sample. This finding speaks to the lack of experience that younger parents may have with raising children and the increased stress that they may endure as a result (Streisand, Braniecki, Tercyak, \& Kazak, 2001). Though parents ages 65 and older are less likely to still have children living in the home, the increased number of parents who choose to delay having children corroborates this finding since birth rates for women in their thirties and forties have increased since the 1980s (Lamanna \& Riedmann, 2006).

In addition to age, we found a statistically significant difference in the odds of experiencing . no child behavior problems for respondents who reported having a high school diploma, some college, or a college degree. Previous studies found parents' educational level to be an important predictor of children's educational and behavioral outcomes (Davis-Kean, 2005; Dearing, McCartney, \& Taylor, 2001; Nagin \& Tremblay, 2001; Smith, Brooks-Gunn, \& Klebanov, 1997). Most of these studies suggested that parents with more education were more likely to have_children who experienced positive outcomes. We found only a high 
Table 4

Logistic Regression Analysis of Sociodemographic Variables and Psychological Distress Predicting no Child Behavior Problems (Model 2)

\begin{tabular}{|c|c|c|c|c|c|}
\hline \multirow[b]{2}{*}{ Variable } & \multicolumn{5}{|c|}{ No Child Behavior Problems $(n=843)$} \\
\hline & B & SE & $\begin{array}{l}\text { Odds } \\
\text { ratio }\end{array}$ & $\begin{array}{l}\text { Wald } \\
\text { Statistic }\end{array}$ & $\begin{array}{l}95 \% \\
\text { C. I. }\end{array}$ \\
\hline $\begin{array}{l}\text { Age } \\
\qquad \begin{array}{r}18-34 \\
35-54 \\
55-64 \\
65+\#\end{array}\end{array}$ & $\begin{array}{l}-.732 \\
-.915 \\
-.367\end{array}$ & $\begin{array}{l}.288 \\
.260 \\
.313\end{array}$ & $\begin{array}{l}.481 \\
.400 \\
.693\end{array}$ & $\begin{array}{l}13.37^{* *} \\
6.48^{*} \\
12.36^{* * *} \\
1.38\end{array}$ & $\begin{array}{l}.27-.85 \\
.24-.67 \\
.38-1.3\end{array}$ \\
\hline $\begin{array}{l}\text { Household Size } \\
1 \\
2 \\
3 \\
4 \\
5+\#\end{array}$ & $\begin{array}{l}1.19 \\
.632 \\
.398 \\
.476\end{array}$ & $\begin{array}{l}.364 \\
.265 \\
.247 \\
.241\end{array}$ & $\begin{array}{l}3.27 \\
1.88 \\
1.49 \\
1.61\end{array}$ & $\begin{array}{l}12.14^{*} \\
10.64^{* * *} \\
5.67^{*} \\
2.60 \\
3.90^{*}\end{array}$ & $\begin{array}{l}1.6-6.7 \\
1.1-3.2 \\
.92-2.4 \\
1.0-2.6\end{array}$ \\
\hline $\begin{array}{l}\text { Education } \\
\text { Less than HS } \\
\text { HS } \\
\text { Some college } \\
\text { College degree \# }\end{array}$ & $\begin{array}{l}.142 \\
.677 \\
.504\end{array}$ & $\begin{array}{l}.259 \\
.242 \\
.248\end{array}$ & $\begin{array}{l}1.15 \\
1.97 \\
1.66\end{array}$ & $\begin{array}{l}10.88^{*} \\
.302^{*} \\
7.84^{* *} \\
4.11^{*}\end{array}$ & $\begin{array}{l}.69-1.9 \\
1.2-3.2 \\
1.0-2.7\end{array}$ \\
\hline Psychological Distress & -.726 & .101 & .484 & $51.95^{* * *}$ & $.40-.59$ \\
\hline Constant & 1.98 & .390 & 7.24 & $25.70^{* * *}$ & \\
\hline
\end{tabular}

${ }^{*} p<.05 . *{ }^{* *}<.01 .{ }^{* * *} p<.001$, Nagelkerke $R^{2}=.190$, \# comparison category

school diploma to produce statistical significance with our first model. Yet once work and family stressors were added, we found that higher educational attainment produced statistically significant differences in the odds of experiencing child behavior problems. One interpretation of this finding is that the respondents with more education are employed by demanding jobs that require them to work long hours, taking time away from their personal life and child-rearing responsibilities. Parents under such stressors may benefit from a partner or another adult with whom they can share the responsibilities associated with raising and rearing children. Our initial findings underscore that the complex nature of work and family stressors may be more influential on child behavior problems than parents' education. Though exploratory in nature, these models do increase our understanding of how education and the relationship status of parents may influence child behavior problems. Future studies should include such models to help further research on the education levels of parent-child interactions as well as how this contributes to child behavior problems.

With regard to marital status and spousal problems, we found that divorced respondents experienced about the same amount of child behavior problems as their married counterparts with spousal problem. Experiencing spousal problems was not predictive of child behavior problems in our study. Similarly, there were no major differences in child behavior problems between married respondents who had spousal problems and those who reported no spousal problems. Our findings are in opposition to those of Cavanaugh and Huston (2006) as well as Nievar and Luster (2006), as both of these studies found marital conflict to be significantly 
Table 5

Logistic Regression Analysis of Sociodemographic Variables, Psychological Distress, and Work and Family Stressors Predicting no Child Behavior Problems (Model 3)

\begin{tabular}{|c|c|c|c|c|c|}
\hline \multirow[b]{2}{*}{ Variable } & \multicolumn{5}{|c|}{ No Child Behavior Problems $(n=599)$} \\
\hline & B & $\mathrm{SE}$ & $\begin{array}{l}\text { Odds } \\
\text { ratio }\end{array}$ & $\begin{array}{l}\text { Wald } \\
\text { Statistic }\end{array}$ & $\begin{array}{l}95 \% \\
\text { C. I. }\end{array}$ \\
\hline $\begin{array}{l}\text { Age } \\
\qquad \begin{array}{r}18-34 \\
35-54 \\
55-64 \\
65+\#\end{array}\end{array}$ & $\begin{array}{l}-1.03 \\
-.858 \\
-.750\end{array}$ & $\begin{array}{l}.449 \\
.416 \\
.443\end{array}$ & $\begin{array}{l}.359 \\
.424 \\
.473\end{array}$ & $\begin{array}{l}5.34 \\
5.21^{* *} \\
4.25^{* *} \\
2.87\end{array}$ & $\begin{array}{l}.15-.87 \\
.19-.96 \\
.20-1.2\end{array}$ \\
\hline $\begin{array}{l}\text { Household Size } \\
\qquad \begin{array}{l}1 \\
2 \\
3 \\
4 \\
5+\#\end{array}\end{array}$ & $\begin{array}{l}1 . \overline{13} \\
.233 \\
.552 \\
.145\end{array}$ & $\begin{array}{l}.596 \\
.344 \\
.320 \\
.293 \\
.\end{array}$ & $\begin{array}{l}3.11 \\
1.26 \\
1.74 \\
1.16\end{array}$ & $\begin{array}{l}5.64 \\
3.61 \\
.457 \\
2.97 \\
.247\end{array}$ & $\begin{array}{l}.97-1.0 \\
.64-2.5 \\
.93-3.3 \\
.65-2.1\end{array}$ \\
\hline $\begin{array}{l}\text { Education } \\
\text { Less than High School } \\
\text { High School } \\
\text { Some college } \\
\text { College degree \# }\end{array}$ & $\begin{array}{l}-.078 \\
.669 \\
.723\end{array}$ & $\begin{array}{l}.332 \\
.294 \\
.296\end{array}$ & $\begin{array}{l}.925 \\
1.95 \\
2.06\end{array}$ & $\begin{array}{l}12.19^{* *} \\
.056 \\
5.18^{*} \\
5.96^{*}\end{array}$ & $\begin{array}{l}.48-1.8 \\
1.1-3.5 \\
1.2-3.7\end{array}$ \\
\hline Psychological Distress & -.296 & 1.40 & .744 & $4.49^{*}$ & $.57-.98$ \\
\hline Bothered as a parent & .937 & .116 & 2.55 & $64.85 * * *$ & $2.0-3.2$ \\
\hline Work Hassles (yes) & -.262 & .235 & .770 & 1.242 & $4.9-1.2$ \\
\hline Work/family balance problems (yes) & -.764 & .240 & .466 & $10.13 * * *$ & $.29-.75$ \\
\hline Marital status, Spousal problems & & & . & $7.32 *$ & \\
\hline Married, No & .895 & .349 & 2.45 & 6.59 & $1.2-4.8$ \\
\hline Married, Yes & 5.36 & .402 & 1.71 & 1.78 & $.78-3.8$ \\
\hline Divorced, Inap\# & & & & & . \\
\hline Constant & -1.74 & .804 & .176 & $4.67^{*}$ & \\
\hline
\end{tabular}

${ }^{*} \mathrm{p}<.05 .{ }^{* *} \mathrm{p}<.01 .{ }^{* * *} \mathrm{p}<.001 .$, Nagelkerke $\mathrm{R}^{2}=.408, \#=$ comparison category

related to child behavior problems. Future studies will need to test the agents involved in the relationship status of parents and provide a richer understanding of how the varying degrees of marital status and mental health influence child behavior problems.

Comparable to previous studies, we found that respondents who reported experiencing psychological distress also reported more child behavior problems than respondents who did not report psychological distress (Hoard; 2004; Panuzio, Taft, Black, Koenen, \& Murphy, 2007; Street, King, King, \& Riggs, 2003). Further, we also found that respondents who were divorced, had trouble balancing work and family, and reported feeling bothered as a parent, all reported increased child behavior problems. Interestingly, excluding the four work and family stressor variables from our model resulted in an increased influence of psychological 
distress on the odds of child behavior problems for our sample. However, adding the work and family stressors to the model resulted in a decreased influence of psychological on the odds of child behavior problems. One interpretation of this finding is that as work and family stressors worsen, the psychological distress of the parents is not as detrimental to their children as the parents' role in raising their children and their ability to balance their work and home responsibilities. Among younger parents, these findings may be more prominent as the ability to maintain the responsibilities of a job and family may be more challenging for younger adults than it is for older adults. Future studies should test models that include more measures of parental mental health as well as work and family conditions to understand the role of these factors in child behavioral outcomes.

\section{LIMITATIONS}

Although this study is distinct in that it examines child behavior problems as influenced by psychological distress and other work and family stressors, we encourage readers to interpret our findings in the context of its limitations. First, we recognize that our findings are limited due to the dichotomous nature of our dependent variable and that one cannot truly determine what it means for a parent to answer "yes" to the question "Have you experienced any problems with your child/children in the past month?" The binomial nature of this variable challenges the reliability and validity of this measure of behavioral difficulties among children. Second, a self-reported instrument was used to gather study data. Therefore, responses emerged from respondents' self-reported accounts. Previous studies have used instruments such as the Children's Beliefs about Parental Divorce Scale (CBAPDS), Children's Depression Inventory (CDI), Beck Depression Inventory, and/or the Relationship Questionnaire, which asks questions more specific to family challenges and child behavior outcomes. We suspect that using more established scales such as these would strengthen the work reported in future studies. Third, our interpretation of the results are limited because the DAS did not include sufficient data on the respondents' children including key variables that would be needed to interpret the results like child age and gender. We were not able to ascertain details about the respondents' children; therefore, there may be additional genderspecific determinants that influence female versus male child behavior problems. McCabe (1997) and Hines (1997) both acknowledged that the gender of the child could highly relate to the way in which the child deals with the result of family challenges, such as divorce. Then, as Amato (2000) and McCabe (1997) found, it is important to acknowledge how old the child is at the time of family status changes since the age of the child is strongly associated with how the child will handle the family dynamics not only at the time it occurred but also as they grow and develop.

Next, though our study included male and female respondents, there is limited work on father involvement and their influence on child behavior problems. Due to the more pronounced roles of fathers in the lives of their children, one potential next step in this research is to examine the work and family stressors of mothers compared to fathers, and assess how this affects child behavior outcomes. In addition, few studies have explored the racial context among African American families with regard to parental mental health and child behavior problems. For instance, parental depression has been found to influence behavior outcomes for African American children, as well as the parent-child relationship (Aikens, Coleman, \& Barbarin, 2008; Hammen, 2003). The present study does not include a racial/ethnic breakdown because our aim was to further the understanding of the influence of sociodemographic variables and psychological distress on child behavior problems. Still, future research would benefit from an additional level of analysis that includes race and cultural context of psychological distress, work and family stressors, and child behavior 
problems. Considering additional mental health measures (e.g., depression and anxiety) would also be advantageous in future studies. Finally, these cross-sectional data cannot help resolve the important question of whether child behavior problems lead to parent mental distress and/or work family conflict; as opposed to the other way around, as we have tested in this study. In light of these limitations, this study was able to uncover the influence of sociodemographic variables and psychological distress on child behavior problems by considering important work and family stressors. Researchers interested in exploring the influence of family, work, and mental health dynamics on childhood behaviors should consider these findings and advance this area of inquiry by developing models that consider the multiple factors that encompass the family and how these factors could potentially influence the child's behavior and adjust their services accordingly.

\section{CONCLUSION}

This study explored the effects of psychological distress and work and family stressors on child behavior problems using the 1995 Detroit Area Study. Findings encourage readers to consider different programmatic strategies for the child depending on the age, education level, marital status, and mental health of the parents. According to our findings, psychological distress and work and family stressors do not affect all children the same way. In order to promote safe and loving transitions for the child, examining different factors that may influence the child's emotional development, life transitions, and mental health trajectories is an advantageous approach. Therefore, an intersectional approach to the study of work and family stressors would advance this research as well as pinpoint areas of practice by service professionals. The results of this study render useful research, service, and policylevel implications to advance this area of inquiry and further this agenda.

\section{REFERENCES}

Abidin, R. R. (1995). Parenting stress index. Psychological Assessment Resources: Odessa, FL.

Aikens, N. L., Coleman, C. P., \& Barbarin, O. A. (2008). Ethnic differences in the effects of parental depression on preschool children's socioemotional functioning. Social Development, 17(1), 137-160.

Altmann, E. O., \& Gotlib, I. H. (1988). The social behavior of depressed children: An observational study. Journal of Abnormal Child Psychology, 16(1), 29-44.

Amato, P. R. (2000). The consequences of divorce for adults and children. Journal of Marriage and Family, 62(4), 1269-1287.

Anthony, L. G., Anthony, B. J., Glanville, D. N., Naiman, D. Q., Waanders, C., \& Shaffer, S. (2005). The relationships between parenting stress, parenting behavior and preschoolers' social competence and behavior problems in the classroom. Infant and Child Development, 14, 133-154.

Beardslee, W. R., Versage, E. M. \& Ǵladstone, T. R. G. (1998). Children of affectively ill parents: a review of the past 10 years. Journal of the American Academy of Child and Adolescent Psychiatry, 37, 1134-1141.

Bigatti, S. M., Cronan, T. A., \& Anaya, A. (2001). The effects of maternal depression on the efficacy of a literacy intervention program. Child Psychiatry \& Human Development, 32(2), 147-162.

Blazer, D. G., Kessler, R. C., McGonagle, K. A., \& Swartz, M. S. (1994). The prevalence and distribution of major depression in a national community sample: The national comorbidity survey. American Journal of Psychiatry, 151(7), 979-986.

Bowen, G. (1998). Effects of leader support in the work unit on the relationship between work spillover and family adaptation. Journal of Family and Economic Issues, 19, 25-52. 
Carlson, M. J., \& Corcoran, M. E. (2001). Family structure and children's behavioral and cognitive outcomes. Journal of Marriage and Family, 63(3), 779-792.

Cavanaugh, S. E., \& Huston, A. C. (2006). Family instability and children's early problem behavior. Social Forces, 85, 551-581.

Christensen, A., Phillips, S., Glasgow, R. E., \& Johnson, S. M. (1983). Parental characteristics and interactional dysfunction in families with child behavior problems: A preliminary investigation. Journal of Abnormal Child Psychology, 11(1), 153-166.

Creasey, G., \& Reese, M. (1996). Mothers' and fathers' perceptions of parenting hassles: associations with psychological symptoms, nonparenting hassles, and child behavior problems. Journal of Applied. Developmental Psychology, 17(3), 393-406.

Crnic, K.A., Gaze, C., Hoffman, C. (2005). Cumulative parenting stress across the preschool period: Relations to material parenting and child behavior at age 5. Infant and Child Development, 14, $117-132$.

Crouter, A. C., Bumpus, M. E, Maguire, M. C., \& McHale, S. M. (1999). Linking parents' work pressure and adolescents' well-being: Insights into dynamics in dual-earner families. Developmental Psychology, 35, 1453-1461.

Dadds, M. R. (1987). Families and origins of child behavior problems. Family Process, 26, 341-357.

Dadds, M. R., Sanders, M. R., Morrison, M., \& Rebgetz, M. (1992). Childhood depression and conduct disorder: II. An analysis of family interaction patterns in the home. Journal of Abnormal Psychology, 101(3), 505-513.

Davis-Kean, P. E. (2005). The influence of parent education and family income on child achievement: The indirect role of parental expectations and the home environment. Journal of Family Psychology, 19,2, 294-304.

Dearing, E., McCartney, K., \& Taylor, B. A. (2006). Within-child associations between family income and externalizing and internalizing problems. Developmental Psychology, 42(2), 237-252.

De Bellis, M. D., \& Thomas, L. A. (2003). Biologic findings of post-traumatic stress disorder and child maltreatment. Current Psychiatry Reports, 5(2), 108-117.

Gardner, F. (2000). Methodological issues in direct observation of parent-child interaction: Do observational findings reflect the natural behavior of participants? Clinical Child and Family Psychology Review, 3, 185-198.

Greenbaum, P. E., Dedrick, R. F., Friedman, R. M., Kutash, K., Brown, E. C., Lardieri, S. P., \& Paugh, A. M. (1996). National adolescent and child treatment study (NACTS) outcomes for children with serious emotional and behavioral disturbance. Journal of Emotional and Behavioral Disorders, 4(3), 130-146.

Greenberg, M. T., Speltz, M. L., \& Deklyen, M. (1993). The role of attachment in the development of disruptive behavior problems. Development and Psychopathology, 5, 191-213.

Hammen, C. (2003). Interpersonal stress and depression in women. Journal of Affective Disorders, 74(1), 49-57.

Hines, A. M. (1997). Divorce-related transitions, adolescent development, and the role of the parentchild relationship: A review of the literature. Journal of Marriage and Family, 59(2), 375-388.

Hoard, L. R. (2004). Chronic illness and behavioral problems in children: Mediating and moderating influences. Dissertation: University of Maryland. Retrieved from http://hdl.handle.net/1903/1578

Jaffee, S. R., Moffitt, T. E., Caspi, A., \& Taylor, A. (2003). Life with (or without) father: the benefits of living with two biological parents depend on the father's antisocial behavior. Child Development, 74(1), 109-126.

Kahn, R. S., Brandt, D. P., \& Whitaker, R. C. (2004). Combined effect of mothers' and fathers' mental health symptoms on children's behavioral and emotional well-being. Archives of Pediatrics \& Adolescent Medicine, 158(8), 721-729. 
Kessler, R. C., Andrews, G., Colpe, L. J., Hiripi, E., Mroczek, D. K., Normand, S. - L. T., Walters, E. E., \& Zaslavsky, A. (2002). Short screening scales to monitor population prevalances and trends in nonspecific psychological distress. Psychological Medicine. 32(6), 959-976.

Kirby, J. B. (2002). The influence of parental separation on smoking initiation in adolescents. Journal of Health and Social Behavior, 43(1), 56-71.

Kuhns, J. B., \& Widom, C. S. (1996). Childhood victimization and subsequent risk for promiscuity, prostitution, and teenage pregnancy: A prospective study. American Journal of Public Health, 86(11), 1607-1612.

Lamanna, M. A., \& Riedman, A. (2006). Marriage and families: Making choices in a diverse society. California: Thomson Wadsworth.

Leiferman, J. (2002). The effect of maternal depressive symptomatology on maternal behaviors associated with child health. Health Education \& Behavior, 29(5), 596-607.

Marmorstein, N. R., Malone, S. M., \& Iacono, W. G. (2004). Psychiatric disorders among offspring of depressed mothers: associations with paternal psychopathology. The American Journal of Psychiatry, $161,1588-1594$.

McCabe, K. M. (1997). Sex differences in the long term effects of divorce on children. Journal of Divorce \& Remarriage, 27(1), 123-135.

McLeod, J. D., \& Nonnemaker, J. M. (1999). Social stratification and inequality. In C. S. Aneshensel \& J. C. Phelan (Eds.), Handbook of the sociology of mental health (pp. 321-344). New York: Kluwer Academic/Plenum.

McLoyd, V. C. (1990). The impact of economic hardship on black families and children: Psychological distress, parenting, and socioemotional development. Child Development, 61, 311-346.

Meadows, S. O., McLanahan, S. S., \& Brooks-Gunn, J. (2007). Parental depression and anxiety and early childhood behavior problems across family types. Journal of Marriage and Family, 69(5), 1162 1177.

Mezulis, A. H., Hyde, J. S., \& Clark, R. (2004). Father involvement moderates the effect of maternal depression during a child's infancy on child behavior problems in kindergarten. Journal of Family Psychology, 18(4), 575-588.

Mowbray, C. T., Bybee, D., Oyserman, D., Allen-Meares, P., MacFarlane, P., \& Hart-Johnson, T. (2004). Diversity of outcomes among adolescent children of mothers with mental illness." Journal of Emotional and Behavioral Disorders, 12(4): 206-21.

Mufson, L., Nomura, Y., \& Warner, V. (2002). The relationship between parental diagnosis, offspring temperament and offspring psychopathology: A longitudinal analysis. Journal of Affective Disorders, 71(1), 61-69.

Naerde, A., Tambs, K., Mathiesen, K., Dalgard, O., \& Samuelsen, S. (2000). Symptoms of anxiety and depression among mothers of pre-school children: Effect of chronic strain related to children and child care-taking. Journal of Affective Disorders, 58, 181-199.

Nagin, D. S., \& Tremblay, R. E. (2001). Parental and early childhood predictors of persisted physical aggression in boys from kindergarten to high school. Archives of General Psychiatry, 58(4), 389-394.

Nievar, M. A., \& Luster, T. (2006). Developmental processes in African American families: an application of McLoyd. Journal of Marriage and Family, 68(2), 320-331.

Olson, S. L., Ceballo, R., \& Park, C. (2002). Early problem behavior among children from low-income, mother-headed families: A multiple risk perspective. Journal of Clinical Child Psychology, 31, 419-430.

Paden, S. L., \& Buehler, C. (1995). Coping with the dual-income lifestyle. Journal of Marriage and the Family, 57, 101-110.

Panuzio, J., Taft, C. T., Black, D. A., Koenen, K. C., \& Murphy, C. M. (2007). Relationship abuse and 
victims' posttraumatic stress disorder symptoms: Associations with child behavior problems. Journal of Family Violence, 22, 177-185.

Perry-Jenkins, M., Repetti, R. L., \& Crouter, A. C. (2000). Work and family in the 1990s. Journal of Marriage and Family, 62(4), 981-998.

Petterson, S. M., \& Albers, A. B. (2001). Effects of poverty and maternal depression on early child development. Child Development, 72(6), 1794-1813.

Phares, V., Duhig, A. M., \& Watkins, M. M. (2002). Family context: Fathers and other supports. In S. H. Goodman, \& I. H. Gotlib (Eds.), Children of depressed parents: Mechanisms of risk and implications for treatment (pp. 203-225). Washington, DC: American Psychological Association.

Piquero, A. R., Farrington; D. P., Welsh, B. C., Tremblay, R., \& Jennings, W. G. (2009). Effects of early family/parent training programs on antisocial behavior and delinquency. Journal of Experimental Criminology, 5(2), 83-120.

Reading, R., \& Reynolds, S. (2001). Debt, social disadvantage and maternal depression. Social Science and Medicine, 53(4), 441-453.

Slade, E. P., \& Wissow, L. S. (2004). Spanking in early childhood and later behavior problems: A prospective study of infants and young toddlers. Pediatrics, 113, 1321-1330.

Smith, J., Brooks-Gunn, J., \& Klebanov, P. K. (1997). The consequences of living in poverty for young children's cognitive and verbal ability and early school achievement. In G. J. Duncan \& J. BrooksGunn (Eds.), Consequences of growing up poor (pp. 132-189). New York: Russell Sage Foundation Press.

Springer, K. W., Sheridan, J.; Kuio, D., \& Carnes; M. (2007). Long-term physical and mental health consequences of childhood physical abuse: Results from a large population-based sample of men and women. Child Abuse \& Neglect, 31, 517-530.

Street, A. E., King, L. A., King, D. W., \& Riggs, D. S. (2003). The associations among maleperpetrated partner violence, wives' psychological distress and children's behavior problems: A structural equation modeling analysis. Journal of Comparative Family Studies, 34, 23-40.

Streisand, R., Braniecki, S., Tercyak, K. P., \& Kazak, A. E. (2001). Childhood illness-related parenting stress: the pediatric inventory for parents. Journal of Pediatric Psychology, 26(3), 155-162.

Thomas, C., \& Evelyn, B. J. (2004). Parents with psychosis. Annals of Clinical Psychiatry: The official Journal of the American Academy of Clinical Psychiatrists, 16(1), 35 - 39. Todorova, I. L. G., Falcón, L. M., Lincoln, A. K., Price, L. L. (2010). Perceived discrimination, psychological distress and health. Sociology of Health \& Illness, 32(6), 843-861.

Williams, D. R., Yu, Y., Jackson, J., Anderson, N. B. (1997). Racial difference in physical and mental health: Socioeconomic status, stress, and discrimination. Journal of Health Psychology, 2(3), 335-351. 
Copyright of Journal of Comparative Family Studies is the property of Journal of Comparative Family Studies and its content may not be copied or emailed to multiple sites or posted to a listserv without the copyright holder's express written permission. However, users may print, download, or email articles for individual use. 